Скляренко І.Ю., Раховецький А.А., Коваленко А.Г., Івко П.П.

\title{
ПЧДВИЩЕННЯ БЕЗПЕКИ МОРЕПЛАВСТВА НА ВОДНИХ ШЛЯХАХ
}

У статті розглянуто проблеми забезпечення безпеки мореплавства на водних шляхах, наведено фактори впливу на морський транспорт, дано визначення системі управління безпекою мореплавства на водних шляхах, що являє собою комплексну організаційнотехнічну систему, яка виконує функиії аналізу стану, контролю й забезпечення безпеки як окремий функиіональних елементів, так і системи в цілому. Досліджено, щуо використання принципів системного аналізу для забезпечення безпеки мореплавства на водних шляхах 3 урахуванням показників безпеки й оцінок ризиків функціонування дозволить підвищити безпеку роботи морських транспортних систем, висунуто основні завдання й визначено функиії системи управління безпекою мореплавства. Представлені суб'єкти управління безпекою мореплавства, включаючи міжнародні організачії, урядові організачії, компанії, порти, сервісні компанії. Представлені об'єкти управління безпекою мореплавства, включаючи системи, проекти, програми, організачіi та підприємства, які відповідальні за реалізачію безпеки.

Ключові слова: система управління, фактори впливу, суб'єкти, об'єкти, безпека, мореплавство.

Постановка проблеми. Проблема забезпечення безпеки мореплавства на водних шляхах сьогодні є в пріоритеті, оскільки ціна аварій на світовому морському флоті у зв'язку 3 глобалізацією світової торгівлі та транспортних процесів останнім часом незмірно зросла, масштаби наслідків набули глобального характеру. Від успішного вирішення даної проблеми залежить життя та здоров'я членів екіпажу, збереження вантажів й водних транспортних засобів [5].

Забезпечення безпеки мореплавства на водних шляхах - це сукупність заходів, пов'язаних із досягненням необхідного рівня надійності та живучості судна, що забезпечують безпечну його діяльність на водних шляхах $[7,8]$.

Мета роботи. Метою дослідження являється застосування системного підходу до розробки проекту створення системи управління безпекою мореплавства на водних шляхах.

Виклад основного матеріалу досліджень. Рівень транспортної безпеки мореплавства залежить, в основному, від взаємодії негативних (загроз) і позитивних факторів впливу (рис. 1) [1-2].

Об'скт дослідження - це діяльність по управлінню безпекою мореплавства на водних шляхах. Центральним органом виконавчої влади, діяльність якого спрямовується i координується Кабінетом Міністрів України через Міністерство інфраструктури і який реалізує державну політику з питань безпеки на наземному транспорті та у сфері безпеки на морському та річковому транспорті (крім сфери безпеки мореплавства суден флоту рибного господарства), являється Державна служба України 3 безпеки на транспорті (Укртрансбезпека) [3]. 


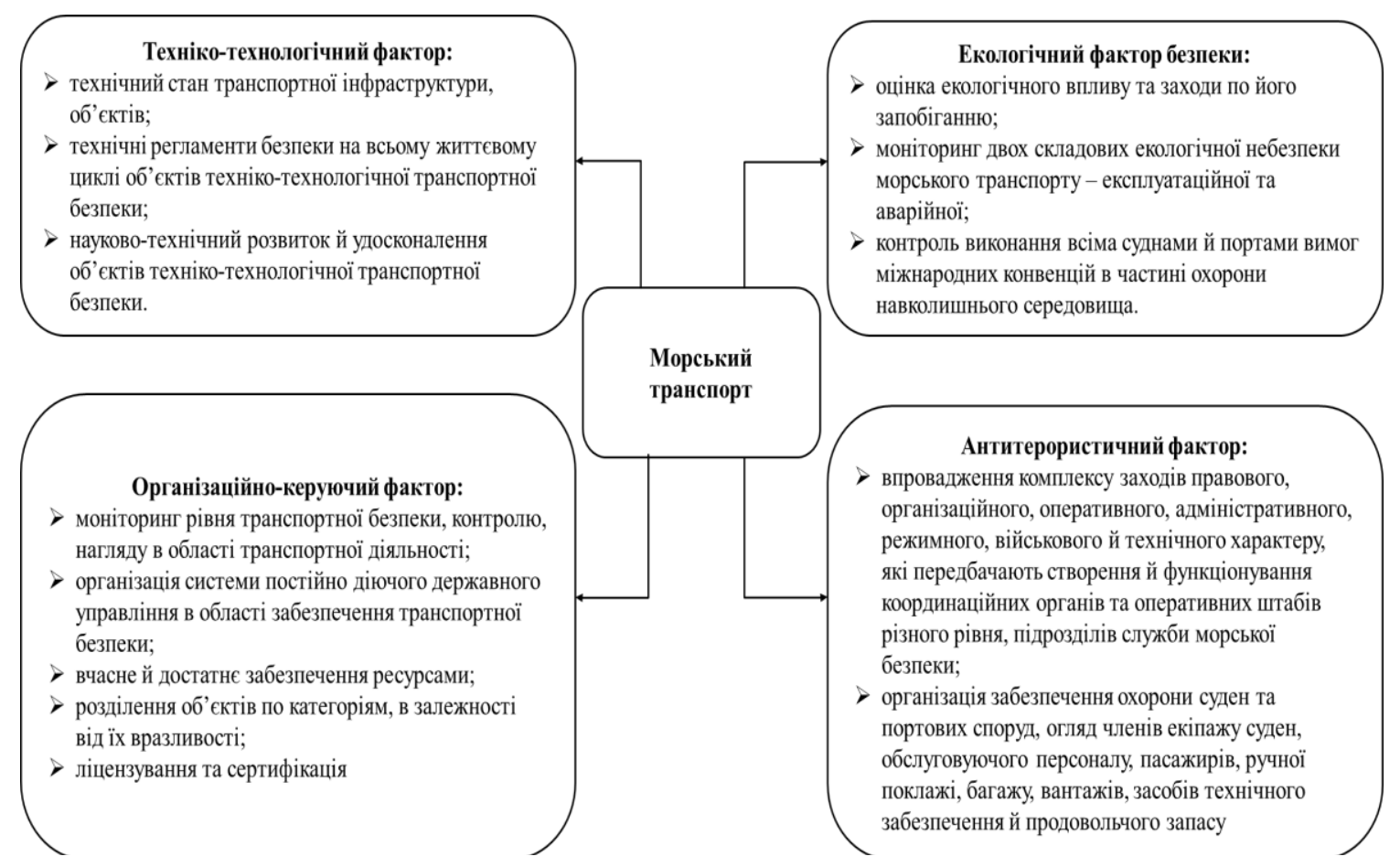

Рисунок 1 - Фактори впливу на морський транспорт

Основні функції Укртрансбезпеки: здійснення державного нагляду (контролю) за безпекою на транспорті, забезпечення надання адміністративних послуг, проведення розслідувань аварій та катастроф на транспорті, нормативно-правове забезпечення безпеки на транспорті, виконання пріоритетних завдань, визначених актами i дорученнями Президента України, Уряду України, щодо забезпечення безпеки перевезень і підвищення безпекових стандартів.

Відсутність комплексного методичного забезпечення формування рівня транспортної безпеки в залежності від впливу факторів впливу на морський транспорт (рис. 1) - основний недолік в реалізації задач поставлених перед Укртрансбезпекою.

Вирішення задачі забезпечення безпеки мореплавства на водних шляхах передбачає впровадження спеціалізованої системи управління. Система управління безпекою мореплавства на водних шляхах являє собою комплексну організаційно-технічну систему, яка виконує функції аналізу стану, контролю й забезпечення безпеки як окремий функціональних елементів, так і системи в цілому [6].

В результаті виконаного аналізу літературних джерел можна зробити висновок, що використання принципів системного аналізу для забезпечення безпеки мореплавства на водних шляхах 3 урахуванням показників безпеки й оцінок ризиків функціонування дозволить підвищити безпеку роботи морських транспортних систем та висунути основні завдання й визначити функції системи управління безпекою мореплавства на водних шляхах [4, 9-10]:

1) Головною метою системи управління безпекою мореплавства на водних шляхах $є$ забезпечення безпечного функціонування морського транспорту й попередження аварійних подій.

2) Головними завданнями системи управління безпекою мореплавства на водних шляхах $є$ :

- абезпечення безпечної експлуатації суден, безпеки суднового персоналу, пасажирів, схоронності вантажів, запобігання забрудненню довкілля із суден;

- забезпечення належного стану шляхів руху суден, функціонування берегових об'єктів морського транспорту та безпеки берегового персоналу;

- забезпечення пошуку і рятування людей та суден на морі, ліквідація небезпечних забруднень морського середовища. 
3) Система управління безпекою мореплавства на водних шляхах також має розв'язувати такі завдання:

- організацію управління безпечною експлуатацією суден та запобігання забрудненню довкілля із суден;

- контроль та нагляд за безпекою судноплавства;

- укомплектування суден кваліфікованими екіпажами, організацію несення вахти, праці та відпочинку;

- організацію навігаційно-гідрографічного та гідрометеорологічного забезпечення безпеки судноплавства;

- інформаційне забезпечення судноплавства зі своєчасним сповіщенням про зміну навігаційної і гідрометеорологічної обстановки та загрозу безпеці судноплавства;

- організацію лоцманського та льодового проведення суден, регулювання руху суден;

- організацію морських систем радіозв'язку, зв'язку на внутрішніх водних шляхах; забезпечення надійного зв'язку у разі виникнення аварійних подій та під час ліквідації ії наслідків;

- створення нормативно-правової бази безпеки судноплавства шляхом адаптації національного законодавства до міжнародних стандартів 3 питань безпеки судноплавства, розробки та впровадження норм і правил національного законодавства, які регламентують судноплавство;

- розробку та виконання програм підвищення рівня безпеки судноплавства;

- розслідування аварійних подій, аналіз, розробку та впровадження відповідних заходів попередження;

- належне реагування сил і засобів з пошуку, рятування та ліквідації небезпечних забруднень довкілля із суден у морській зоні відповідальності України;

- забезпечення безпеки експлуатації гідротехнічних та інших споруд, які використовуються для потреб судноплавства;

- ліцензування господарської діяльності з надання послуг з перевезення пасажирів i вантажів морським і річковим транспортом;

- сертифікація судноплавної компанії, суден, інших об'єктів управління;

- забезпечення належного вирішення інших завдань 3 безпеки судноплавства відповідно до зобов'язань України за ііі міжнародними договорами у сфері судноплавства.

4) До функцій системи управління безпекою мореплавства на водних шляхах належать:

- організація роботи, яка передбачає:

- визначення суб'єктів та об'єктів управління безпеки судноплавства;

- встановлення функціональних обов'язків структурних підрозділів та посадових осіб 3 питань безпеки судноплавства на всіх рівнях управління та виробництва;

- регламентацію діяльності керівників та посадових осіб;

- нормативне забезпечення управління безпекою судноплавства.

- інформування про стан безпеки судноплавства, яке складається з:

- передачі інформації в установленому порядку;

- отримання та цільового збирання інформації про стан безпеки судноплавства;

- обліку та систематизації інформації;

- аналізу показників аварійності та стану безпеки судноплавства;

- підготовки висновків і відповідних пропозицій.

- оперативне реагування на виникнення аварійних подій та розслідування обставин та причин аварійних подій, яке складається з:

- отримання інформації про аварійні події;

- попередньої оцінки та класифікації аварійних подій;

- організації та проведення пошукових та аварійно-рятувальних робіт;

- розслідування аварійних подій;

- оцінки стану безпеки на об'єктах управління, де сталися аварійні події;

- аналізу, обліку та передачі інформації про аварійні події;

- підготовки і впровадження заходів попередження.

- планування та виконання робіт, яке включає: 
- розробку та вжиття заходів (програм) 3 підтримки та підвищення рівня безпеки судноплавства і попередження аварійних подій;

- організацію виконання (реалізації) прийнятих заходів (програм);

- супроводження (контроль) на всіх етапах виконання заходів (програм);

- аналіз та оцінку результатів, прийняття в установленому порядку результатів виконаних заходів (програм).

- спеціальні функції, які включають:

- підтвердження відповідності;

- сертифікацію суден, судноплавних компаній, плавскладу, окремих елементів берегової інфраструктури морського транспорту;

- ліцензування окремих видів діяльності.

- розповсюдження i обмін інформацією 3 питань безпеки судноплавства, яка здійснюється шляхом:

- використання засобів масової інформації;

- проведення днів, тижнів, місячників безпеки;

- проведення конференцій, семінарів, нарад;

- здійснення роз'яснювальної роботи.

- контрольні та наглядові функції, які включають:

- постійний контроль функціонування системи управління безпекою мореплавства на водних шляхах ;

- державний нагляд над станом безпеки судноплавства на морському транспорті;

- планові перевірки за затвердженими графіками;

- позапланові (позачергові) перевірки;

- комплексні перевірки;

- цільові перевірки.

- функція підготовки та реалізації управлінських рішень, яка складається з:

- підготовки рішення;

- прийняття рішення;

- реалізації рішення;

- контролю над процесом реалізації рішення.

Розробка системи управління безпекою мореплавства на водних шляхах (рис. 2) має три основних блока, які представлені структурними декомпозиціями суб'єктів управління, об’єктів управління та процесу управління.

Суб'єкти управління. Суб'єктами управління являються активні учасники системи УБМ (проекту), які взаємодіють при виробленні та прийнятті рішень в процесі його розробки. До суб'єктів управління відносяться: замовник (Укртрансбезпека), проектувальник, підрядник, виконавець і ін., менеджер проекту, адміністратор проекту, представники проекту, функціональні менеджери проекту.

Об'єкти управління. Об'єктами управління можуть бути:

- системи та підсистеми УБМ;

- безліч проектів, портфелі проектів і програм в підрозділах Укртрансбезпеки або компаніях;

- періоди життєвого циклу об'єкта управління: концепція, розробка, реалізація, виконання.

Процес управління розробкою системи безпеки мореплавства. Це вплив суб'єктів управління на об'єкти управління за допомогою прийнятих рішень задач УБМ. Підставами класифікації завдань УБМ є:

- стадії процесу управління, включаючи: розробку концепції системи УБМ, планування розробки УБМ, організацію і контроль виконання робіт по УБМ, аналіз і регулювання ходу розробки УБМ, закриття проекту і його частин;

- функиіональні області управління, включаючи: предметну область, тимчасові параметри, вартість, якість, ризики, персонал, комунікації, контракти, зміни та інші; 
- часові розрізи управління, включаючи: стратегічний рівень - охоплює весь життєвий цикл системи УБМ; річний рівень; квартальний рівень; оперативний рівень; кризовий рівень управління.

\begin{tabular}{|c|c|c|c|}
\hline \multicolumn{4}{|c|}{ Суб์'єкти управління } \\
\hline \multicolumn{4}{|c|}{ Учасники проекту розроблення УБМ } \\
\hline Замовник & Проектувальник & Підрядник & Виконавці \\
\hline \multicolumn{4}{|c|}{ Команда проекту розроблення УБМ } \\
\hline Менеджер проекту & $\begin{array}{c}\text { Адміністратор } \\
\text { проекту }\end{array}$ & $\begin{array}{c}\text { Представники } \\
\text { проекту }\end{array}$ & $\begin{array}{c}\text { Функціональні } \\
\text { менеджери }\end{array}$ \\
\hline \multicolumn{4}{|c|}{ Об'єкти управління } \\
\hline \multicolumn{4}{|c|}{ Проекти і програми УБМ } \\
\hline Проекти & Програми & $\begin{array}{c}\text { Організації, } \\
\text { Підприємства }\end{array}$ & геми \\
\hline \multicolumn{4}{|c|}{ Періоди життєвого циклу УБМ } \\
\hline Концепція & Розробка & Реалізація & Виконання \\
\hline \multicolumn{4}{|c|}{ Процес управління } \\
\hline \multicolumn{4}{|c|}{ Рівні УБМ } \\
\hline Стратегічний & Поточний & Оперативний & Кризовий \\
\hline \multicolumn{4}{|c|}{ Функціональні області УБМ } \\
\hline Предмет & Чac & Вартість & Якість і т.д. \\
\hline \multicolumn{4}{|c|}{ Стадії процесу УБМ } \\
\hline Ініціювання & Планування & Регулювання & Контроль і аналіз \\
\hline
\end{tabular}

Рисунок 2 - Розробка системи управління безпекою мореплавства

На основі системної моделі розробки УБМ можна здійснювати інтеграцію різних пї елементів. Об'єднуючи елементи моделі зверху вниз можна отримати вертикальну інтеграцію суб'єктів управління, об'єктів управління і процесу управління за обраними елементами системної моделі.

Це дозволяє визначити завдання (процеси), необхідні для замовника, проектувальника, менеджера проекту. Не менш важливими є завдання, які визначаються різними комбінаціями елементів кожного рівня системної моделі, - горизонтальна інтеграція. Така інтеграція може об'єднувати всі елементи або частина елементів (їх комбінацію). Найбільше практичне значення і застосування мають завдання, які визначаються горизонтально-вертикальною або змішаною інтеграцією елементів системної моделі.

Пропонована системна модель $є$ методологічним інструментарієм для генерації i системного проектування цілісної інтегрованої системи УБМ, яка може бути використана на всіх етапах іiі розробки, включаючи:

- концептуальне проектування;

- проектування функціональних і забезпечуючих частин;

- проектування системи комунікацій і документації; 
- розробку елементів: моделі, методи, алгоритми, програми та нормативно-методичне забезпечення (керівництво користувачам, корпоративні та системні стандарти, методики, інструкції).

Висновки. Формування функціональної структури завдань системної моделі дозволяє здійснити класифікацію задач i процедур, можливих при управлінні проектами та програмами безпеки судноплавства. Пропонований підхід дозволяє виявити склад проблемно-орієнтованих комплексів процесів (завдань) УБМ, визначити методи й інструментарій забезпечення ефективного прийняття рішень на всіх рівнях системи УБМ.

\section{ЛІТЕРАТУРА}

1. Семанов Г.Н. Морской транспорт и экологическая безопасность Электронный ресурс. -Режим доступа : http://mi32.narod.ru/01-99/safity.html.

2. Skrynnik, A. M. The state management in the sphere of maintenance of sea safety in Russia [Text] / A. M. Skrynnik // Severo-Kavkazskii iuridicheskii vestnik. - 2009. - No. 3. - P. $77-84$.

3. Про затвердження Положення про Державну службу України з безпеки на транспорті [Електронний ресурс]: Постанова Кабінету Міністрів України від 11 лютого 2015 року №103. - Режим доступу: https://zakon.rada.gov.ua/laws/show/103-2015-\%D0\%BF\#Text.

4. Про затвердження Положення про систему управління безпекою судноплавства на морському i річковому транспорті [Електронний ресурс]: Наказ Міністерства транспорту України від 20.11.2003 №904. - Режим доступу: https://zakon.rada.gov.ua/laws/show/z1193-03\#Text.

5. Про схвалення Транспортної стратегії України на період до 2020 року: Розпорядження Кабінету Міністрів України від 20 жовтня 2010 р. // Офіційний вісник України. - 2010. № 92, т. 2. Ст. 3280 .

6. Щодо стратегічних пріоритетів реалізації потенціалу України як морської держави: аналітична доповідь / А.О. Филипенко, В.В. Баришнікова, К.В. Степанова [та ін.]. О.: Фенікс, 2012. - 152 с.

7. Борисова Л.Ф. Анализ причин столкновения судов и проблемы безопасности мореплавания. Наука и образование: Материалы Междунар. научно-техн. конф. (Мурманск, 7-15 апреля 2004). Мурманск, МГТУ, ч.5, с.245-249, 2004.

8. Скороходов Д.А., Стариченков А.Л., Хабарова И.В. Разработка методологии управления безопасностью транспортных систем). Отчет о НИР (промежуточный). СПб., ИПТРАН, 135 с., 2004.

9. Review of maritime transport 2011, report by the unCtAd secretariat.: [Електронний ресурс]. - Режим доступу: http://archive.unctad.org/templates/webflyer.asp?docid=15876\&in tItemId=2068\&lang=1\&mode=downloads

10. Ильницкий К. Два десятилетия водного транспорта Украины [Електроний ресурс] / К. Ильинский // Порты Украины. - 2011. - № 6. - Режим доступу: http://portsukraine. com/node/2169

\section{REFERENCES}

1. Semanov GN Maritime transport and environmental safety Electronic resource. -Access mode: http://mi32.narod.ru/01-99/safity.html.

2. Skrynnik, A. M. The state management in the sphere of maintenance of sea safety in Russia [Text] / A. M. Skrynnik // Severo-Kavkazskii iuridicheskii vestnik. - 2009. - No. 3. P. 77-84.

3. On approval of the Regulation on the State Service of Ukraine for Transport Safety [Electronic resource]: Resolution of the Cabinet of Ministers of Ukraine of 11 February 2015 №103. - Access mode: https://zakon.rada.gov.ua/laws/show/103-2015$\%$ D0\%BF\#Text. 
4. On approval of the Regulations on the safety management system of shipping on sea and river transport [Electronic resource]: Order of the Ministry of Transport of Ukraine dated 20.11.2003 №904. - Access mode: https://zakon.rada.gov.ua/laws/show/z1193-03\#Text.

5. On approval of the Transport Strategy of Ukraine for the period up to 2020: Order of the Cabinet of Ministers of Ukraine of October 20, 2010 // Official Gazette of Ukraine. - 2010. № 92, vol. 2. Art. 3280 .

6. On the strategic priorities of the potential of Ukraine as a maritime state: an analytical report / A.O. Filipenko, V.V. Baryshnikov, K.V. Stepanova [etc.]. - O.: Fenix, 2012. - 152 c.

7. Borisova LF Analysis of the causes of ship collisions and maritime safety issues. Science and education: Materials International. scientific and technical conf. (Murmansk, April 715, 2004). Murmansk, Moscow State Technical University, Part 5, pp.245-249, 2004.

8. Skorokhodov D.A., Starichenkov A.L., Khabarova I.V. Development of safety management methodology for transport systems). Research report (intermediate). SPb., IPTRAN, 135 p., 2004.

9. Review of maritime transport 2011, report by the unCtAd secretariat .: [Electronic resource]. - Access mode: http://archive.unctad.org/templates/webflyer.asp?docid=15876\&in tItemId $=2068 \&$ lang $=1 \&$ mode $=$ downloads

10. Ilnitsky K. Two decades of water transport of Ukraine [Electronic resource] / K. Ilyinsky // Ports of Ukraine. - 2011. - № 6. - Access mode: http: // portsukraine. com / node / 2169

\section{Sklyarenko I.Y., Rakhovetsky A.A., Kovalenko A.G., Ivko P.P.}

\section{INCREASING SAFETY ON NAVIGATION ON WATERWAYS}

The article considers the problems of maritime safety on waterways, the factors influencing maritime transport, defines the management system of maritime safety on waterways, which is a comprehensive organizational and technical system that performs the functions of analysis, control and safety as a separate functional elements and the system as a whole. It is investigated that the use of the principles of system analysis to ensure the safety of navigation on waterways, taking into account safety indicators and assessments of operational risks will improve the safety of maritime transport systems, the main tasks and defined the functions of maritime safety management system. Maritime safety management entities are represented, including international organizations, government organizations, companies, ports, service companies. Maritime safety management facilities are presented, including systems, projects, programs, organizations and enterprises responsible for the implementation of safety.

Keywords: management system, factors of influence, subjects, objects, safety, navigation.

\section{Скляренко И.Ю., Раховецкий А.А., Коваленко А.Г., Ивко П.П. ПОВЫШЕНИЕ БЕЗОПАСНОСТИ МОРЕПЛАВАНИЯ НА ВОДНЫХ ПУТЯХ}

В статье рассмотрены проблемы обеспечения безопасности мореплавания на водных путях, приведены факторы влияния на морской транспорт, дано определение системь управления безопасностью мореплавания на водных путях, представляет собой комплексную организаџионно-техническую систему, которая выполняет функиии анализа состояния, контроля и обеспечения безопасности как отдельных функциональных элементов, так и системы в целом. Доказано, что использование принцииов системного анализа для обеспечения безопасности мореплавания на водных путях с учетом показателей безопасности и оценок рисков функционирования позволит повысить безопасность работь морских транспортных систем, предъявлено основнье задачи и определень функции системь управления безопасностью мореплавания. Представленнь субъекть управления безопасностью мореплавания, включая международные организации, правительственные организации, компании, порты, сервисные компании. Представлень объекты управления безопасностью мореплавания, включая системы, проекты, программы, организации и предприятия, ответственные за реализаџию безопасности.

Ключевье слова: система управления, факторы влияния, субъекты, объекты, безопасность, мореходность. 